\title{
Aquatic Viruses and Climate Change
}

\author{
Rui Zhang ${ }^{1}$, Markus G. Weinbauer ${ }^{2}$ and Peter Peduzzi ${ }^{3, *}$ \\ ${ }^{1}$ Institute of Marine Microbes and Ecospheres; and State Key Laboratory of Marine \\ Environmental Science, Xiamen University (Xiang'an), Xiamen, Fujian, China; \\ ${ }^{2}$ Microbial Ecology and Biogeochemistry Group, Laboratoirè d'Oceanographie de \\ Villefranche, Universitè Pierre et Marie Curie-Paris 6, Villefranche-sur-Mer, France, \\ and CNRS, Laboratoire d'Ocèanographie de Villefranche, Villefranche-sur-Mer, \\ France; ${ }^{3}$ University of Vienna, Faculty of Life Sciences, Functional and Evolutionary \\ Ecology, Limnology Unit, Vienna, Austria; * corresponding author
}

Email: ruizhang@xmu.edu.cn, zhangray@gmail.com,wein@obs-vlfr.fr, peter.peduzzi@univie.ac.at

DOI: https://doi.org/10.21775/cimb.041.357

\begin{abstract}
The viral component in aquatic systems clearly needs to be incorporated into future ocean and inland water climate models. Viruses have the potential to influence carbon and nutrient cycling in aquatic ecosystems significantly. Changing climate likely has both direct and indirect influence on virus-mediated processes, among them an impact on food webs, biogeochemical cycles and on the overall metabolic performance of whole ecosystems. Here we synthesise current knowledge on potential climate-related consequences for viral assemblages, virus-host interactions and virus functions, and in turn, viral processes contributing to climate change. There is a need to increase the accuracy of predictions of climate change impacts on virusdriven processes, particularly of those linked to biological production and biogeochemical cycles. Comprehension of the relationships between microbial/viral processes and global phenomena is essential to predict the influence on as well as the response of the biosphere to global change.
\end{abstract}




\section{Introduction}

Whereas most human interventions on ecosystems are immediate, the impact on climate change acts over long periods of time, leading to slight but continuous alterations. As an example, the predicted $2.6-4.8^{\circ} \mathrm{C}$ warming, under the conditions of Representative Concentration Pathways 8.5 (IPCC, 2013), for this century is expected to be responsible for species movements and extinctions, as well as for changes in the composition of communities, thus likely altering ecosystem functioning (Mooney et al., 2009). Since global change will probably impact all ecosystem components, it is expected that even the smallest life-forms such as Bacteria, Archaea, eukaryotic microorganisms and viruses of aquatic systems will play important roles as agents and recipients of global climate change (Danovaro et al., 2011; Hutchins and Fu, 2017).

Beside direct effects by changes in water temperature, others may occur through altered oceanic circulation along with changing habitats, biogeochemical cycles and food webs. Particularly estuaries and continental shelf regions seem to be affected by changed river runoff due to reduced or enhanced precipitation and flooding. This will result in changes in salinity and nutrients, and in the strength and seasonality of circulation patterns (Danovaro et al., 2011; Cozzi et al., 2012). Changing ocean currents, fluctuations in the depth of the surface mixed layer and stratification might influence light and nutrient availability and ultimately $\mathrm{CO}_{2}$ dynamics and the carbon cycle (Bauer et al., 2013; Finke et al., 2017). Moreover, warming will increase the extent of the oxygen minimum zones (OMZ), which are a globally important sink for nitrogen and a source of $\mathrm{CO}_{2}$. Another global player is the reduction of seawater $\mathrm{pH}$ due to enhanced $\mathrm{CO}_{2}$ levels in the atmosphere (ocean acidification, OA). OMZ changes and OA will also influence virus-host interactions.

For inland waters and freshwater systems a whole array of human-mediated threats makes them the most affected ecosystems. Beside pollution and nutrient loads, overexploitation, flow modification, habitat destruction or degradation, climate change is designated as a significant factor for ongoing alterations of these systems (Dudgeon et al., 2006; Zweimüller et al., 2008). There is also evidence that climate warming will affect pelagic carbon metabolism and sediment delivery in lakes and carbon sequestration in streams and rivers (Battin et al., 2009; Boyero et al., 2011; Kritzberg et al., 2014). 
Global climate change-related impacts are most striking in the polar regions, where temperature and other factors are changing at more than twice the global average (Hoegh-Guldberg and Bruno, 2010). Due to the major contribution of microbes to ecosystem processes, much attention has been paid to the impact of rapid climate change in Arctic and Antarctic microbial communities (e.g., the European Project on Ocean Acidification, EPOCA). Declines or shifts in these microbial ecosystems will no doubt have implications for entire food webs and biogeochemical fluxes, and polar microbiota can be viewed both as sentinels and amplifiers of global change (Vincent, 2010).

The global relevance of aquatic viruses has been evident for many years. Viruses are the smallest and most numerous biological entities in aquatic ecosystems, the majority being bacteriophages (Wommack and Colwell, 2000; Weinbauer, 2004; Suttle, 2007). They are about 10 to 15 -fold more abundant than their microbial hosts, and equivalent to the carbon in ca. 75 million blue whales (ca. 10\% of prokaryotic carbon by weight; Suttle, 2005). The typically high frequency of virus infection in aquatic ecosystems is known to be a major cause of prokaryotic host mortality. Host cell lysis in the marine environment was calculated to be a source of up to $10^{9}$ tons of carbon each day, released from the biological pool (Suttle, 2007; Brussaard et al., 2008). If the main control of prokaryotic abundance is via protozoan grazing, most of the carbon will be channelled to higher trophic levels (microbial loop). In contrast, if viral lysis accounts for most prokaryotic losses, then carbon and nutrients are diverted away from larger organisms (Proctor and Fuhrman, 1990; Wilhelm and Suttle, 1999). The biogeochemical consequence of this "viral shunt" (the process of diverting organic carbon away from the grazing food chain via viral lysis of host cells) are changed rates of carbon accumulation in the photic zone $\left(\mathrm{CO}_{2}\right.$ release to the atmosphere vs. vertical transport to the meso-/bathypelagic zone). Viruses are also involved in shaping the composition of bacterial communities, either by reducing abundant host taxa or even by introducing new genetic information into their hosts (e.g., Zhang et al., 2007). They are the largest and most diverse genetic reservoir on Earth and may boost the resilience of ecosystems by sustaining multiple species with similar or identical biochemical pathways (Thingstad, 2000; Brussard et al., 2008; Jacquet et al., 2010; Brum et al., 2015; Guidi et al., 2016; Gregory et al., 2019).

Elucidating the microbial mediation of carbon-cycle feedbacks to climate change appears to be fundamental for understanding ecosystem responses. This 
approach would provide a mechanistic basis for carbon-climate modelling (Zhou et al., 2011). Our substantial lack of knowledge explains why the viral compartment is missing from most climate change models. This review tackles the growing evidence that aquatic viruses interact actively with climate alterations and are key biotic components that can influence the microbial feedback on climate change (compare also Danovaro et al., 2011; Mojica and Brussaard, 2014).

\section{Impact on viral abundance, distribution and dynamics}

In most natural aquatic environments virus communities were found to be highly dynamic, with often pronounced changes in abundance and diversity over broad ranges of space and time. Viral abundance is largely linked to host availability. The numbers of planktonic viruses commonly range between $10^{4}$ and $10^{8} \mathrm{ml}^{-1}$, being generally higher in inland waters than in marine systems; peak values were reported for very productive estuaries and lakes (Peduzzi and Luef, 2009; Parikka et al., 2017). Exceptionally high virioplankton abundance has been documented in the alkalinesaline lake Nakuru in Kenya, East Africa (up to $7 \times 10^{9} \mathrm{ml}^{-1}$; Peduzzi et al., 2014). Abundance may be up to three orders of magnitude lower in deep oceanic waters (e.g. Parada et al., 2006; Magagnini et al., 2007; Li et al., 2014; Liang et al., 2014; Lara et al. 2017; Muck et al. 2014), but virus-induced relative prokaryotic mortality increases with water depth: below a depth of $1000 \mathrm{~m}$ almost all of the prokaryotic heterotrophic production in surface sediment is transformed into organic detritus and dissolved organic matter (DOM). This "viral shunt" releases on a global scale 0.37-0.63 Gt carbon year ${ }^{-1}$, and is an essential source of labile organic matter for the deep-sea ecosystem (Danovaro et al., 2008). Recently, Lara et al. (2017) estimated that about $145 \mathrm{Gt}$ of C, $27.6 \mathrm{Gt}$ of N, and 4.6 Gt of P are released annually by the viral shunt in global tropical and subtropical oceans. Moreover, on average, 33.6\% (equalling 0.605

$\mathrm{Pg}\left(\right.$ year $\left.^{-1}\right)$ of the globally respired carbon from fluvial systems may pass through a viral loop (Peduzzi, 2016).

Factors affecting virus dynamics and microbial host-virus interactions in the marine environment have been summarized (Mojica and Brussaard, 2014). Typically virus numbers are linked to system productivity, as a result of the balance between production and decay. Eutrophic water bodies contain more virus particles than oligotrophic systems (Parikka et al., 2017). The trophic situation can also be very variable on seasonal scales, particularly in running waters with pronounced hydrological dynamics (Peduzzi, 2016). Virus abundance apparently varies more 
pronouncedly on seasonal scales in inland waters than in the marine environment (Wilhelm and Matteson; 2008).

\section{Impact of temperature}

The typical viral life cycles (lytic and lysogenic) and replication rates are closely linked with host metabolism. As temperature is a major regulatory factor of microbial growth, an increase in temperature will likely affect the interaction between viruses and their hosts (Mojica and Brussaard, 2014). With increasing prokaryote growth rate, burst size can increase while the length of the lytic cycle decreases (Proctor et al., 1993; Hadas et al., 1997), boosting virus production. Higher temperatures should also increase the contact rates between viruses and hosts (Murray and Jackson, 1992) and hence potentially infection. Although evidence across systems is scarce, increases in burst size together with increases in production have been described for some natural systems (e.g. Parada et al., 2006). Danovaro et al. (2011) suggested that the observed relationship between viral abundance and temperature from different oceanic regions could be used to infer evidence for the potential effect of rising seasurface temperatures. With these compiled data, the strongest effect was detected in temperate-open oceans: a temperature increase of only a few degrees was accompanied by a doubling in viral abundance. Nonetheless, factors influencing virioplankton distribution are clearly more complex than predicted by temperature alone. This is underlined by the observation that, when global data were grouped together, an overall decreasing pattern of viral abundance with increasing temperature was identified. This inverse relationship suggests that latitudinal changes, which influence radiation regimes and trophic characteristics, can display cascade effects on growth rates of hosts and viral infectivity (Danovaro et al., 2011). A large data set from the Atlantic Ocean revealed that temperature was important in the Sargasso Sea, but not in the northeast Atlantic (Rowe et al., 2008). In experiments over short time scales, changes in temperature did not directly influence viral abundance (Feng et al., 2009).

In the same compilation of literature data, Danovaro et al. (2011) showed that, in cold water systems, higher viral production rates were associated with warmer temperatures, whereas the relationship for systems at tropical and mid-latitudes was less clear. They concluded that different oceanic regions would respond differently to changes in surface temperatures caused by climate change. These temperatureassociated changes in viral abundance and production are likely secondary effects 
caused by changes in host cell communities and in virus decay rates (Nagasaki and Yamaguchi, 1998; Wells and Deming, 2006). Demory et al. (2017) demonstrated that at suboptimum temperatures, lytic cycle kinetics of a Micromonas virus were lengthened and viral yield was reduced. Temperature increase shortened the latent periods, increased the burst size, and affected viral infectivity (Maat et al., 2017). Higher temperature will increase viral decay by enhanced activity of extracellular proteases and nucleases (Suttle and Chen, 1992; Noble and Fuhrman, 1997; Corinaldesi et al., 2010; Wei et al., 2018). In addition, alteration of temperature may affect protein stability and biomolecule elasticity of viral capsid proteins or lipid membranes, and influence the folding and binding of proteins and nucleic acids (Mojica and Brussaard, 2014). An experimental study in two contrasting Arctic systems (Lara et al., 2013) revealed that heterotrophic bacterial and viral abundance, bacterial production and grazing by protists increased at higher experimental temperatures. It remains to be elucidated whether predictable seasonal changes in hosts and viruses are applicable for climate-related long-term and large-scale changes (Danovaro et al., 2011).

The molecular mechanisms and the environmental factors behind the lysogenic decision are still not well understood (Long et al., 2008). The present climate-related changes in environmental conditions (temperature, circulation of water masses, nutrient availability, alterations in system productivity, coastal mixing with freshwater, etc.) may significantly influence viral life strategies. Lysogeny is thought to be favoured under low nutrient concentrations and high virus-to-host cell ratios (Wilson and Mann, 1997). Thus, if nutrient availability becomes limited due to increased vertical stratification caused by rising sea surface temperatures (Sarmiento et al., 2004), a substantial shift to the lysogenic life cycle may be the consequence. Conversely coastal and estuarine environments may shift to increase favouring of the lytic life-style with large-scale implications on heterotrophic and autotrophic organisms (Danovaro et al., 2011). However, Vaqué et al. (2019) found rather the inverse trend related to temperature. Knowles et al. (2016) suggested that lysogeny is also favoured at high bacterial production rates (Piggyback-the-Winner model). As temperature increases will influence growth, there could be also a change in viral life strategies. The direct and indirect effects of temperature on viruses and their interaction with hosts remain to be investigated in more detail. 


\section{Effect of changing salinity}

Freshening of the oceanic environments due to climate change has been discussed particularly for poleward regions, and freshwater increases of the Arctic Ocean are suggested as being linked to respective changes of the North Atlantic as well (Peterson et al. 2002; Peltier et al., 2006). Changes in salinity can also influence viral lifestyles (Williamson and Paul, 2006), but experimental studies reveal no consistent pattern regarding the lytic-lysogenic-decision (Danovaro et al., 2011 and references therein), whereas Bettarel et al. (2011) found a switch from lytic to lysogenic life styles at high salinity. Recently, viral lysogeny and lysis shifts related to spring-neap tidal cycle were observed in a macrotidal subtropical estuary, which may be caused by freshwater-seawater mixing dynamics (Chen et al., 2019). Either induction or increased phage latent periods have been found under elevated sodium chloride concentrations. There is evidence that salinity can be of importance for the burst size of infected cells. In waters with high salinity, large burst sizes (up to 200) have been described (Guixa-Boixareu et al., 1996). Furthermore, in freshwater environments burst sizes are typically higher than in marine systems (Peduzzi and Luef, 2009). Mixing of these two environments may result in shifts of host growth rates, DOM availability and burst sizes. An interesting experimental study regarding freshwater and seawater mixing (e.g. as in estuaries) demonstrated that production rates of freshwater viruses sharply declined after seawater addition, followed by a rapid (within $48 \mathrm{~h}$ ) recovery of the viral populations. Conversely, marine viruses were not significantly affected by mixing with freshwater (Cissoko et al., 2008). However, Marine et al. (2013) showed that freshwater prokaryote and virus communities can adapt to a controlled increase in salinity through changes in their structure and interactions. Another study has shown the possibility for freshwater viruses to cross into the marine environment and replicate normally (Sano et al. 2004). These studies and others (Bonilla-Findji et al., 2009; Wei et al. 2019) indicate that viruses can rapidly respond to major shifts in the abundance and community composition of bacterial hosts, which suffer from osmotic shock.

In a meta-analysis Danovaro et al. (2011) showed that systems with lower salinity display higher viral abundance. However, these results could reflect the more specific situation of the sampled areas rather than a general trend because this data set was largely from few estuarine systems. It may also be linked to the different nutrient availability and trophic state of the estuarine environments rather than to a direct 
effect of salinity on the viral assemblages. In addition, Parikka et al. (2017) showed in an across-systems study that the ratio of viruses to prokaryote abundance was inversely related to salinity.

Changes in salinity and $\mathrm{pH}$ can also influence the extent of virus adsorption to particles (Harvey and Ryan, 2004; Mojica and Brussaard, 2014), thus affecting virus distribution and proliferation. Further, enhanced river runoff to the sea will likely increase the particle concentration in coastal regions. In a riverine environment, for example, the quality, size and age of particles and aggregates, and the exposure time of viruses to aggregates, apparently are the key factors regulating viral abundance (Kernegger et al., 2009; Peduzzi, 2016). Importantly, particles (mainly with organic constituents) appear to play a role as viral scavengers or reservoirs rather than viral factories (Weinbauer et al. 2009). Moreover, adsorption of viruses to suspended particles can stimulate growth of the free-living prokaryotic community, e.g. by reducing viral lysis (Peduzzi and Luef, 2008; Weinbauer et al., 2009). In case salinity and particle load play a significant role in community composition, then the predicted sea-level rise, saltwater and freshwater mixing and temperature changes associated with the present global climate change could influence the success of the dominant viral and host taxa.

In those locations where climate change will increase freshwater input and nutrient concentrations, lytic life strategies could become more important through higher burst sizes, increasing infection rates due to the addition of freshwater viruses, and increased growth rates of prokaryotes and phytoplankton (Danovaro et al. 2011). An accelerated prokaryote-virus production cycle will on one hand release more components (e.g. enzymes) that are known as highly active for viral decay (Wommack and Colwell, 2000). On the other hand, increasing amounts of substrate for prokaryotes from the 'viral shunt' will result in larger burst sizes and potentially enhanced rates of adaptation and evolution. Important information could be drawn from additional experimental, proteomic and genomic data analyses in systems with gradients of salinity and from studies on the lifestyle of viruses and their host interactions. The speed and mechanisms of change, which are currently poorly understood, will be the main controlling factors in the shifts along the freshwatermarine continuum (Danovaro et al., 2011). 


\section{Ocean acidification}

The uptake of anthropogenic $\mathrm{CO}_{2}$ in ocean waters is reported to alter the $\mathrm{pH}$ (Riebesell et al., 2009). Nonetheless, predictions of the effect of ocean $\mathrm{pH}$ changes on the viral compartment are difficult. While the direct effects on marine viruses remain uncertain, it is likely that the most significant changes will be caused by the impact on their host organisms, for example on calcifying protists (Danovaro et al., 2011). Another example is the observed sharp drop in nitrification under increased $\mathrm{CO}_{2}$ concentrations (Hutchins et al., 2009), suggesting that viruses from ammoniaoxidising bacteria and archaea might be affected. Furthermore, decreased $\mathrm{pH}$ can affect a broad range of physiological processes in microorganisms, e.g. those based on a proton gradient across membranes. Moreover, a significant fraction of nearsurface prokaryotes was found to carry the pigment proteorhodopsin (which can act as a light-driven proton pump), being quite sensitive to even small decreases in $\mathrm{pH}$ (Fuhrman et al., 2008). In the so far largest $\mathrm{CO}_{2}$ manipulation experiment (European Project on Ocean Acidification, EPOCA), complex impacts on different groups of plankton and on biogeochemical cycles were found (Riebesell et al., 2013, and special volume of Biogeosciences).

The survival, infectivity and adsorption of some bacteriophages were reported to be sensitive to $\mathrm{pH}$ (Harvey et al., 2014) and several studies have demonstrated an influence on the proliferation dynamics of phage-host systems (e.g., Larsen et al., 2008; Carreira et al., 2012; Traving et al., 2014; Chen et al., 2015). Highfield et al. (2017) showed that the diversity of EhV was much lower in the high- $p \mathrm{CO}_{2}$ treatment enclosure that did not show inhibition of $E$. huxleyi growth. In the EPOCA experiment, a significant influence of ocean acidification on the relationship between viral and bacterial abundance was found (Brussaard et al., 2013). Ocean acidification did not affect lytic viral production in mesocosms experiments from the Mediterranean Sea and a Norwegian fjord, but lysogeny was stimulated and either linked to phytoplankton production (Tsiola et al., 2017) or bacterial production (Vaqué et al., 2017). In summary, profound effects related to $\mathrm{pH}$-changes on microbial communities and their viruses have been detected, but the topic remains largely unexplored.

\section{Potential impact of climate change on viruses and carbon cycling}

Knowledge on the interactive role of viruses in global $\mathrm{CO}_{2}$ fluxes is largely in its infancy. Four main $\mathrm{CO}_{2}$ sequestration processes in the ocean are known, the physical 
or solubility pump, the carbonate, the biological pump and the microbial carbon pump (Legendre et al., 2015). Conversion of $\mathrm{CO}_{2}$ into biomass and the subsequent sinking of organic and inorganic components of the plankton in the ocean interior are known as the biological carbon pump. The microbial carbon pump is the conversion of organic matter into forms with low bioavailability (Jiao et al., 2010; Legendre et al., 2015). The effect of rising atmospheric $\mathrm{CO}_{2}$ on ocean acidification and carbonation is also receiving current attention. Factors affecting these processes are relevant to understand the functioning of the largest ecosystem on Earth, and to better comprehend the global carbon cycle and its implications on climate (Riebesell et al., 2009). It is still a largely open question how and to what extent the 'viral shunt' influences the efficiency of the biological pump, the microbial carbon pump and the sequestration of carbon in the ocean interior. After viral infection, a varying but substantial fraction of the released organic material can be more or less efficiently utilized by uninfected heterotrophic prokaryotes, thus entering again the food web. The net effect of the viral shunt is that it detours bacterial production away from being consumed by protists and ultimately converts organic matter into dissolved inorganic nutrients, including respired $\mathrm{CO}_{2}$ (Wilhelm and Suttle, 1999; Suttle, 2007). Viral particles also make a contribution to the pools and fluxes of DOC, DON and DOP in the global oceans (Suttle, 2005; Jover et al., 2014; Zhang, et al., 2014).

In global carbon cycling models viruses are still practically ignored, making it difficult to come up with comprehensive conclusions. One scenario is that viral lysis increases the efficiency of the biological pump by enriching the proportion of carbon in the sinking particulate material (Suttle, 2007). At the same time, a viral-mediated control on the biological pump will potentially be impacted by climate change in that climate-induced warming of surface oceans could increase the mortality of the pelagic prokaryotes; this would cause an increased release of labile dissolved organic matter (DOM) that can enhance the metabolism and respiration of uninfected cells. Furthermore, a meta-analysis of data from the literature suggested that higher temperatures are associated with exponentially higher decay rates of virioplankton, based on higher levels of exoenzymatic activities (Danovaro et al., 2011). Danovaro et al. (2011) present a conceptual scheme of the impact on the biological carbon pump and of potential feedback mechanisms. In that concept, viral lysis, together with rising $\mathrm{CO}_{2}$ concentration, cause changes in phytoplankton composition and production. The result would be a modification of both the photosynthetically 
produced particulate organic (POC) and inorganic (PIC, by calcifying photoautotrophs) carbon. It would also alter the particle export, in particular the relative ratio of PIC to POC in this material. Thus, the flux of $\mathrm{CO}_{2}$ between the ocean surface and the atmosphere would be affected as a possible feedback effect on atmospheric $\mathrm{CO}_{2}$ concentrations. The metabolism of heterotrophic prokaryotic cells could also be enhanced by rising sea-surface temperatures, thus increasing carbon consumption and respiration rates. Two potential scenarios regarding the viralmediated control on the biological pump were suggested (Danovaro et al. 2011). On one hand, by altering the pathways of carbon fluxes in the sea - when converting living organic matter into dead particulate organic matter and DOM via cell lysis - the viral shunt could have a negative effect on the biological pump. DOM from cell lysis will be retained to a greater extent in surface waters, much of it converted to DIC through respiration and photodegradation. On the other hand, the viral shunt could favour carbon sequestration by increasing the nutrient availability for primary producers. This could increase the amount of living POC in surface waters, thus enhancing carbon export. In addition, other studies highlighted the role of viral lysis for the release of dense and refractory colloidal aggregates (Mari et al., 2005), or for the formation and size increase of organic aggregates (Peduzzi and Weinbauer, 1993), suggesting that viral mortality of host cells can favour carbon transport to the deep sea (viral shuttle; (Sullivan et al., 2017; Yamada et al., 2018). As viruses could also produce positively buoyant aggregates (Weinbauer, 2004), the role of aggregates produced by viruses can be described as viral elevator (Weinbauer et al., 2009). The influence of viral lysis on the stability and formation of aggregates may either increase the retention time of particles in the euphotic zone or increase carbon export to the ocean interior (Weinbauer et al., 2009). However, it is still unclear, whether viruses short-circuit or prime the biological pump (Brussaard et al., 2008). Changes in the amount of carbon release into the deep will no doubt influence also the functioning of deep-sea ecosystems (Smith et al., 2008). Recently, it has been shown that viruses play a more significant role for carbon fixation than previously thought; this influence is mediated by auxiliary metabolic genes (AMGs) (Puxty et al., 2016, 2018). This suggests a closer link of viral infection to the carbon cycle. In a recent review, it has been argued that metabolic reprogramming of infected cells and viral lysis alter nutrient cycling and carbon export in the ocean; however, the net impacts remain uncertain (Zimmerman et al., 2020). 
Regarding inland waters the current perception is that the contribution of river networks to fluvial net heterotrophy and $\mathrm{CO}_{2}$ outgassing has been underestimated in the past (Battin, 2008; Raymond et al., 2013; Acuña et al., 2020). Almost nothing, however, is known about the significance of the viral shunt in flowing inland waters (Peduzzi and Luef, 2008; Peduzzi, 2016). Most fluvial systems harbour and transport high amounts of organic carbon (dissolved and particulate). Although viral lysis may release only a small fraction to this large organic carbon pool, it could still contribute significantly to the readily utilizable carbon (labile and semi-labile fraction) and its remineralisation in fluvial systems. This should be particularly relevant in these systems, which are characterised by a high proportion of allochthonous (terrestrial) aged and recalcitrant carbon (Peduzzi, 2016). Pollard and Ducklow (2011) reported for the Australian Bremer River that terrestrial DOC was partly returned to the atmosphere as $\mathrm{CO}_{2}$ through bacterial respiration, assisted by bacteriophage lysis of their hosts. This short-circuits the microbial loop. Since streams and rivers are also subjected to climate change-related temperature shifts (Zweimüller et al., 2008), it is likely that the role of viruses in determining the proportion of organic material in horizontal transport and in processing and remineralisation in fluvial waters will be impacted as well.

\section{Conclusions and outlook}

The growing knowledge on virus ecology of marine and inland water environments has increased the incorporation of virus-related processes into aquatic food web models. Nonetheless, in climate change models the role of viruses is difficult to assess due to the rudimentary studies and data. Viruses can be anticipated as the ultimate nanoscale drivers/regulators of life in the effect they can have on organisms. Accordingly, aquatic viral ecology will contribute importantly, as the effects of climate and anthropogenic forcing in aquatic food webs are resolved step by step (Brussaard et al., 2008; Zimmerman et al., 2020). Changes in water temperature no doubt affect microbial growth, respiratory rates and carbon assimilation. This makes it extremely important to understand the effect of global warming on microbial communities and their central role in the carbon cycle. Temperature increases are also likely to impact the interactions between viruses and their host cells. Clearly, an improved understanding of viral responses to present climate change would enhance our chances to predict and adapt to potential consequences of such changes (compare Danovaro et al., 2011). Virus infection of microbial cells has the potential for 
cascading effects in food webs (Peduzzi et al., 2014). As ocean temperatures rise, precipitation patterns change and freshening of surface oceans occur, simultaneous and intermingled cascading effects may be the result. Global shifts in viral lifestyles in response to changing climate could have dramatic effects on global biogeochemical cycles via cascading effects.

One substantial drawback is the lack of long-term data sets that could be used to identify the relationships between climatic conditions and microbial processes. In a synthesis of the current knowledge and based on relevant case studies, and on metaanalyses of literature data, Danovaro et al. (2011) presented a catalogue of potential consequences and scenarios; some are outlined below together with additional important points:

1. There is some degree of consensus that the effect of temperature on virus related processes will be significant. Effects might be different at different latitudes and oceanic regions (at high latitudes rising temperatures may promote the viral compartment and depress it at the tropics). Increased vertical stratification due to climate change can lead to large-scale nutrient limitations, altering viral life strategies (lytic vs. lysogenic cycle).

2. Changes in salinity and the freshwater-marine continuum will probably impact the abundance, proliferation and life strategies of viruses. They may also influence the geographical success of dominant host taxa and subsequently the success of their viral counterparts. Freshening at the poles may increase the input and spread of freshwater groups of hosts and viruses into marine waters, facilitating enhanced crossing over of marine and freshwater taxa. Apparently, climate change-related impacts are particularly severe in polar regions and the microbiota there might be sentinels of global change.

3. It is currently unclear whether the viral shunt will result in negative or positive effects on the efficiency of the biological pump, and consequently, on the feedback of marine systems on climate. Viruses have the potential to interact with the climate through their contribution to the DOM-pool and to the biogenic particles.

4. The effect of ocean acidification on marine viruses will be largely via the effects of $\mathrm{pH}$ on the host organisms. Since some key metabolic processes of microorganisms are sensitive to changes in $\mathrm{pH}$ of the medium, this may 
profoundly influence the overall functioning of microbial-mediated processes and virus-host interactions.

5. The role of inland waters, in particular streams and rivers, will be largely reevaluated through the current perception that the contribution of river networks to fluvial net heterotrophy and $\mathrm{CO}_{2}$ outgassing has been underestimated in the past. Increased virus activity will probably contribute significantly to the readily utilizable carbon (labile and semi-labile fraction) and its remineralisation. In fluvial waters, climate change-related temperature shifts will influence the role of viruses in determining the proportion of organic material in horizontal transport and in processing and remineralisation.

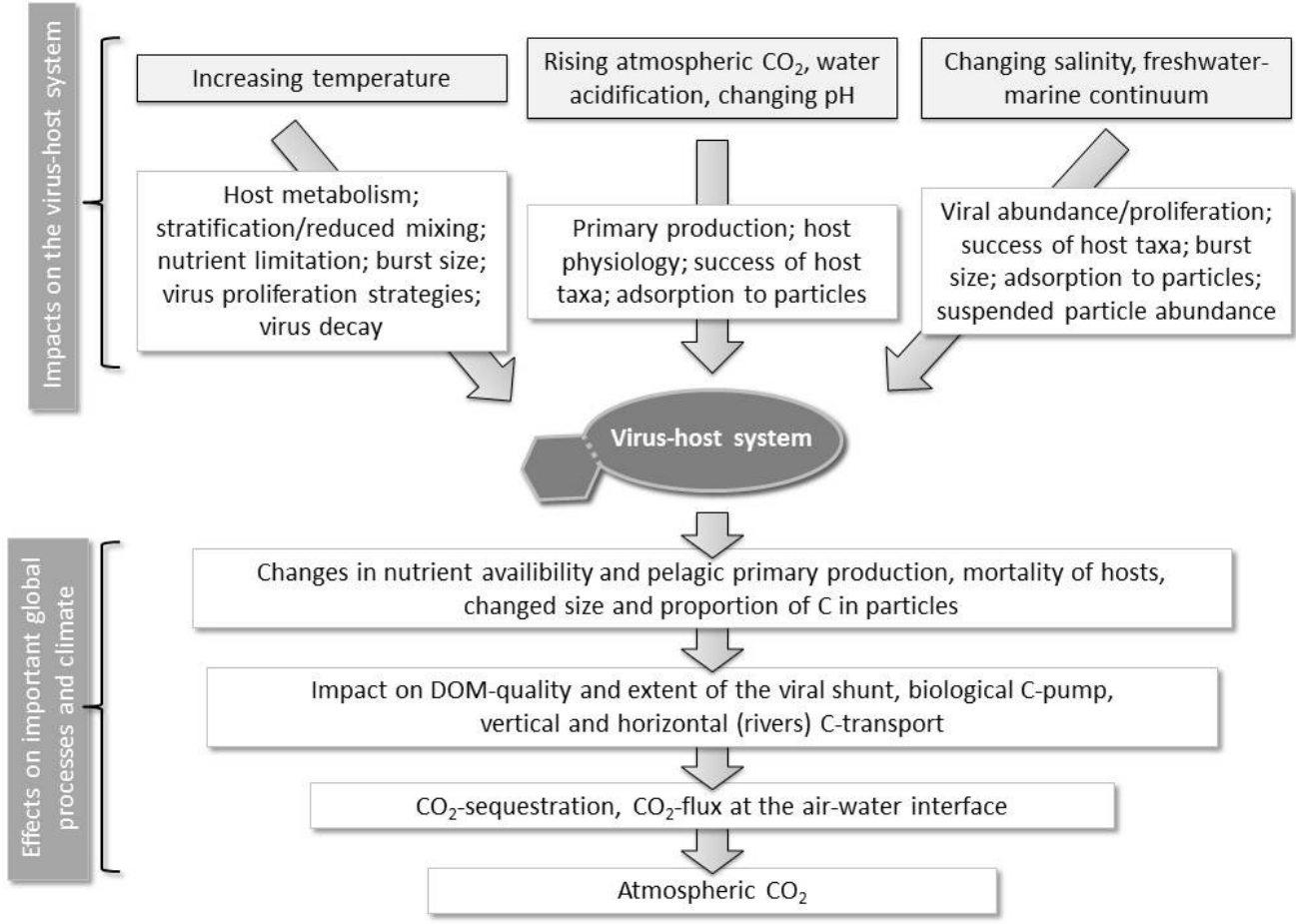

Figure 7.1 Schematic representation of some potentially important impacts of climate change on the virus-host system and potential effects and feedbacks of this biological compartment on some global processes and pools; for details see text. 
6. Enhanced river runoff to the sea and mixing processes will likely increase the particle concentration at least in coastal regions; such particles are important factors regulating viral abundance. Aquatic aggregates apparently play a role as viral scavengers or reservoirs rather than viral factories, and adsorption of viruses to suspended particles may stimulate growth of the free-living prokaryotic community, e.g. by reducing viral lysis.

From all these considerations it can be concluded that aquatic viruses will be significantly influenced by climate change and that viruses, in turn, can influence processes contributing to climate change. In Fig. 7.1 some potentially important impacts, effects and relations of virus-host systems, facing a global climate change, are outlined. Under the present scenario of climate change, however, it remains unclear whether viruses will ultimately destabilise or even stabilise the dynamics of the living components in ecosystems and the related biogeochemical cycles. Due to the dearth of data it is currently unpredictable whether virus-related processes will amplify or smooth the impact of climate change on aquatic systems (Danovaro et al., 2011). These limitations inhibit incorporating virus-related processes into current climate models on the necessary spatial and temporal scales at which climate change scenarios respond and interact with this important compartment of the biosphere. This calls for focused research priorities and long-term data sets to enhance our knowledge about the role of aquatic viruses in the present climate change scenario.

\section{References}

Acuña, V., Freixa, A., Marcé, R., and Timoner, X. (2020). Ecosystem Metabolism in

River Networks and Climate Change. In Climate Change and Microbial Ecology, Current Research and Future Trends, 2nd edition, J. Marxsen, ed. (Norfolk, UK: Caister Academic Press). doi.org/10.21775/9781913652579

Battin, T.J., Kaplan, L.A., Findlay, S., Hopkinson, C.S., Marti, E., Packman, A.I., et al. (2008). Biophysical controls on organic carbon fluxes in fluvial networks. Nature Geosci. 1, 95-100.

Battin, T.J., Luyssaert, S., Kaplan, L.A., Aufdenkampe, A.K., Richter, A., and Tranvik, L.J. (2009). The boundless carbon cycle. Nature Geosci. 2, 598-600.

Bauer, J.E., Cai, W., Raymond, P.A., Bianchi, T.S., Hopkinson, C.S., and Regnier, P.A. (2013). The changing carbon cycle of the coastal ocean. Nature 504, 61-70. 
Bettarel, Y., Bouvier, T., Bouvier, C., Carre, C., Desnues, A., Domaizon, I., et al. (2011). Ecological traits of planktonic viruses and prokaryotes along a full-salinity gradient. FEMS Microbiol. Ecol. 76, 360-372.

Bonilla-Findji, O., Rochelle-Newall, E., Weinbauer, M.G., Pizay, M.D., Kerros, M.E., and Gattuso, J.P. (2009). Effect of seawater-freshwater cross-transplantations on viral dynamics and bacterial diversity and production. Aquat. Microb. Ecol. 54, 111.

Boyero, L., Pearson, R.G., Gessner, M.O., Barmuta, L.A., Ferreira, V., Graça, M.A.S., et al. (2011). A global experiment suggests climate warming will not accelerate litter decomposition in streams but might reduce carbon sequestration. Ecol. Lett. 14, 289-294.

Brum, J.R., Ignacio-Espinoza, J.C., Roux, S., Doulcier, G., Acinas, S.G., Alberti, A., et al. (2015). Patterns and ecological drivers of ocean viral communities. Science. 348, 1261498.

Brussaard, C.P.D, Wilhelm, S.W., Thingstad, F., Weinbauer, M.G., Bratbak, G., Heldal, M., et al. (2008). Global-scale processes with a nanoscale drive: the role of marine viruses. ISME J. 2, 575-578.

Brussaard, C.P.D., Noordeloos, A.A.M., Witte, H., Collenteur, M.C.J., Schulz, K., Ludwig, A., et al. (2013). Arctic microbial community dynamics influenced by elevated $\mathrm{CO}_{2}$ levels. Biogeosciences. 10, 719-731.

Carreira, C., Heldal, M., and Bratbak, G. (2013). Effect of increased $p \mathrm{CO}_{2}$ on phytoplankton-virus interactions. Biogeochemistry 114, 391-397.

Chen, S., Gao, K., and Beardall, J. (2015). Viral attack exacerbates the susceptibility of a bloom-forming alga to ocean acidification. Global. Change Biol. 21, 629-636.

Chen, X., Wei, W., Wang, J., Li, H., Sun, J., Ma, R., et al. (2019). Tide driven microbial dynamics through virus-host interactions in the estuarine ecosystem. Water Res. 160, 118-129.

Cissoko, M., Desnues, A., Bouvy, M., Sime-Ngando, T., Verling, E., and Bettarel, Y. (2008). Effects of freshwater and seawater mixing on virio- and bacterioplankton in a tropical estuary. Freshw. Biol. 53, 1154-1162.

Corinaldesi, C., Dell'Anno, A., Magagnini, M., and Danovaro, R. (2010). Viral decay and viral production rates in continental-shelf and deep-sea sediments of the Mediterranean Sea. FEMS Microbiol. Ecol. 72, 208-218. 
Cozzi, S., Falconi, C., Comici, C., Čermelj, B., Kovac, N., Turk, V., et al. (2012). Recent evolution of river discharge in the Gulf of Trieste and their potential response to climate changes and anthropogenic pressure. Estuar. Coast. Shelf Sci. $115,14-24$.

Danovaro, R., Corinaldesi, C., Dell'anno, A., Fuhrman, J.A., Middelburg, J.J., Noble, R.T., et al. (2011). Marine viruses and global climate change. FEMS Microbiol. Rev. 35, 993-1034.

Danovaro, R., Dell'Anno, A., Corinaldesi, C., Magagnini, M., Noble, R., and Tamburini, C. (2008). Major viral impact on the functioning of benthic deep-sea ecosystems. Nature 454, 1084-1087.

Demory, D., Arsenieff, L., Simon, N., Six, C., Rigaut-Jalabert, F., Marie, D., et al. (2017). Temperature is a key factor in Micromonas-virus interactions. ISME J. 11, 601-612.

Dudgeon, D., Arthington, A.H., Gessner, M.O., Kawabata, Z., Knowler, D.J., Leveque, C., et al. (2006). Freshwater biodiversity: importance, threats, status and conservation challenges. Biol. Rev. 81, 163-182.

Feng, Y., Hare, C.E., Leblanc, K., Rose, J.M., Zhang, Y., DiTullio, G.R., et al. (2009). Effects of increased $\mathrm{pCO}_{2}$ and temperature on the North Atlantic spring bloom. I. The phytoplankton community and biogeochemical response. Mar. Ecol. Prog. Ser. $388,13-25$.

Finke, J.F., Hunt, B.P.V., Winter, C., Carmack, E.C., and Suttle, C.A. (2017). Nutrients and other environmental factors influence virus abundances across oxic and hypoxic marine environments. Viruses 9, 152.

Fuhrman, J.A., Schwalbach, M.S., and Stingl, U. (2008). Proteorhodopsins: an array of physiological roles? Nat. Rev. Microbiol. 6, 488-494.

Gregory, A.C., Zayed, A.A., Conceicao-Neto, N., Temperton, B., Bolduc, B., Alberti, A., et al. (2019). Marine DNA viral macro- and microdiversity from pole to pole. Cell. 177, 1109-1123.

Guidi, L., Chaffron, S., Bittner, L., Eveillard, D., Larhlimi, A., Roux, S., et al. (2016). Plankton networks driving carbon export in the oligotrophic ocean. Nature. 532, 465-470.

Guixa-Boixareu, N., Calderón-Paz, J.I., Heldal, M., Bratbak, G., and Pedrós-Alió, C. (1996). Viral lysis and bacterivory as prokaryotic loss factors along a salinity gradient. Aquat. Microb. Ecol. 11, 215-227. 
Hadas, H., Einav, M., Fishov, 1., and Zaritsky, A. (1997). Bacteriophage T4 development depends on the physiology of its host Escherichia coli. Microbiol. 143, 179-185.

Harvey, R.W., and Ryan, J.N. (2004). Use of PRD1 bacteriophage in groundwater viral transport, inactivation, and attachment studies. FEMS Microbiol. Ecol. 49, 316.

Highfield, A., Joint, I., Gilbert, J.A., Crawfurd, K.J., and Schroeder, D.C. (2017). Change in Emiliania huxleyi virus assemblage diversity but not in host genetic composition during an ocean acidification mesocosm experiment. Viruses 9, 41.

Hoegh-Guldberg, O., and Bruno, J.F. (2010). The impact of climate change on the world's marine ecosystems. Science. 328, 1523-1528.

Hutchins, D., and Fu, F. (2017). Microorganisms and ocean global change. Nat. Microbiol. 2, 17058.

Hutchins, D.A., Mulholland, M.R., and Fu, F. (2009). Nutrient cycles and marine microbes in a $\mathrm{CO}_{2}$-enriched ocean. Oceanography. 22, 128-145.

IPCC (International Panel on Climate Change) (2013). Climate Change 2013: The Physical Science Basis (Cambridge: Cambridge University Press).

Jacquet, S., Miki, T., Noble, R., Peduzzi, P., and Wilhelm, S. (2010). Viruses in aquatic ecosystems: important advancements of the last 20 years and prospects for the future in the field of microbial oceanography and limnology. Adv. Oceanogr. Limnol. 1, 97-141.

Jiao, N., Herndl, G.J., Hansell, D.A., Benner, R., Kattner, G., Wilhelm, S.W., et al. (2010). Microbial production of recalcitrant dissolved organic matter: long-term carbon storage in the global ocean. Nat. Rev. Microbiol. 8, 593-599.

Jover, L.F., Effler, T.C., Buchan, A., Wilhelm, and S.W. Weitz, J.S. (2014). The elemental composition of virus particles: implications for marine biogeochemical cycles. Nat. Rev. Microbiol. 12, 519-528.

Kernegger, L., Zweimuller, I., and Peduzzi, P. (2009). Effects of suspended matter quality and virus abundance on microbial parameters: experimental evidence from a large European river. Aquat. Microb. Ecol. 57, 161-173.

Knowles, B., Silveira, C.B., Bailey, B.A., Barott, K., Cantu, V.A., Cobián-Güemes, A.G., et al. (2016). Lytic to temperate switching of viral communities. Nature 531, 466-470. 
Kritzberg, E.S., Granéli, W., Björk, J., Brönmark, C., Hallgren, P., Nicolle, A., et al. (2014). Warming and browning of lakes: consequences for pelagic carbon metabolism and sediment delivery. Freshw. Biol. 59, 325-336.

Lara, E., Arrieta, J.M., Garcia-Zarandona, I., Boras, J.A., Duarte, C.M., Agustí, S., et al. (2013). Experimental evaluation of the warming effect on viral, bacterial and protistan communities in two contrasting Arctic systems. Aquat. Microb. Ecol. 70, $17-32$.

Lara, E., Vaque, D., Sa, E.L., Boras, J.A., Gomes, A., Borrull, E., et al. 2017. Unveiling the role and life strategies of viruses from the surface to the dark ocean. Sci. Adv. 3, e1602565.

Larsen, J.B., Larsen, A., Bratbak, G., and Sandaa, R.A. (2008). Phylogenetic analysis of members of the Phycodnaviridae virus family, using amplified fragments of the major capsid protein gene. Appl. Environ. Microbiol. 74, 3048-3057.

Legendre, L., Rivkin, R.B., Weinbauer, M., Guidi, L., and Uitz, J. (2015). The microbial carbon pump concept: Potential biogeochemical significance in the globally changing ocean. Prog. Oceanogr. 134, 432-450.

Li, Y., Luo, T., Sun, J., Cai, L., Liang, Y., Jiao, N., et al. (2014). Lytic viral infection of bacterioplankton in deep waters of the western Pacific Ocean. Biogeosciences 11, 2531-2542.

Liang, Y., Li, L., Luo, T., Zhang, Y., Zhang, R., and Jiao, N. (2014). Horizontal and vertical distribution of marine virioplankton: a basin scale investigation based on a global cruise. PLoS One 9, e111634.

Long, A., McDaniel, L.D., Mobberley, J., and Paul, J.H. (2008). Comparison of lysogeny (prophage induction) in heterotrophic bacterial and Synechococcus populations in the Gulf of Mexico and Mississippi River plume. ISME J. 2, 132144.

Maat, D.S., Biggs, T., Evans, C., and van Bleijswijk, J.D.L. (2017). Characterization and temperature dependence of arctic Micromonas polaris. Viruses 9, 134.

Magagnini, M., Corinaldesi, C., Monticelli, L.S., Domenico, E.D., and Danovaro, R. (2007). Viral abundance and distribution in mesopelagic and bathypelagic waters of the Mediterranean Sea. Deep Sea. Res. Pt I. 54, 1209-1220.

Mari, X., Rassoulzadegan, F., Brussaard, C.P.D., and Wassmann, P. (2005). Dynamics of transparent exopolymeric particles (TEP) production by Phaeocystis globosa 
under N- or P-limitation: a controlling factor of the retention/export balance. Harmful Algae 4, 895-914.

Marine, C., Thierry, B., Olivier, P., Emma, R.N., Corinne, B., Martin, A., et al. (2013). Freshwater prokaryote and virus communities can adapt to a controlled increase in salinity through changes in their structure and interactions. Estuar. Coast. Shelf S. 133, 58-66.

Mojica, K.D., and Brussaard, C.P. (2014). Factors affecting virus dynamics and microbial host-virus interactions in marine environments. FEMS Microbiol. Ecol. $89,495-515$.

Mooney, H., Larigauderie, A., Cesario, M., Elmquist, T., Hoegh-Guldberg, O., Lavorel, S., et al. (2009). Biodiversity, climate change, and ecosystem services. Curr. Opin. Environ. Sustain. 1, 46-54.

Muck, S., Griessler, T., Köstner, N., Klimiuk, A., Winter, C., and Herndl, G.J. (2014). Fracture zones in the Mid Atlantic Ridge lead to alterations in prokaryotic and viral parameters in deep-water masses. Front. Microbiol. 5, 264.

Murray, A.G., and Jackson, G.A. (1992). Viral dynamics: a model of the effects of size shape, motion and abundance of single-celled planktonic organisms and other particles. Mar. Ecol. Prog. Ser. 89, 103-116.

Nagasaki, K., and Yamaguchi, M. (1998). Effect of temperature on the algicidal activity and stability of HaV (Heterosigma akashiwo Virus). Aquat. Microb. Ecol. $15,211-216$.

Noble, R.T., and Fuhrman, J.A. (1997). Virus decay and its causes in coastal waters. Appl. Environ. Microbiol. 63, 77-83.

Parada, V., Herndl, G.J., and G.Weinbauer, M. (2006). Viral burst size of heterotrophic prokaryotes in aquatic systems. J. Mar. Biol. Assoc. UK. 86, 613-621.

Parikka, K.J., Le Romancer, M., Wauters, N., and Jacquet, S. (2017). Deciphering the virus-to-prokaryote ratio (VPR): insights into virus-host relationships in a variety of ecosystems. Biol. Rev. Camb. Philos. Soc. 92, 1081-1100.

Peduzzi, P. (2016). Virus ecology of fluvial systems: a blank spot on the map?. Biol. Rev. Camb. Philos. Soc. 91, 937-949.

Peduzzi, P., Gruber, M., Gruber, M., and Schagerl, M. (2014). The virus's tooth: cyanophages affect an African flamingo population in a bottom-up cascade. ISME J. $8,1346-1351$. 
Peduzzi, P., and Luef, B. (2009). Viruses. In G.E. Likens (ed.): Encyclopedia of Inland Waters (Oxford: Elsevier).

Peduzzi, P., and Luef, B. (2008). Viruses, bacteria and suspended particles in a backwater and main channel site of the Danube (Austria). Aquat. Sci. 70, 186-194.

Peduzzi, P., and Weinbauer, M.G. (1993). Effect of concentrating the virus-rich 2-200 $\mathrm{nm}$ size fraction of seawater on the formation of algal flocs (marine snow). Limnol. Oceanogr. 38, 1562-1565.

Peltier, W.R., Vettoretti, G., and Stastna, M. (2006). Atlantic meridional overturning and climate response to Arctic Ocean freshening. Geophy. Res. Lett. 33, L06713.

Peterson, B.J., Holmes, R.M., McClelland, J.W., Vorosmarty, C.J., Lammers, R.B., Shiklomanov, A.I., et al. (2002). Increasing river discharge to the Arctic Ocean. Science. 298, 2171-2173.

Pollard, P.C., and Ducklow, H. (2011). Ultrahigh bacterial production in a eutrophic subtropical Australian river: Does viral lysis short-circuit the microbial loop? Limnol. Oceanogr. 56, 1115-1129.

Proctor, L.M., and Fuhrman, J.A. (1990). Viral mortality of marine bacteria and cyanobacteria. Nature. 343, 60-62.

Proctor, L.M., Okubo, A., and Fuhrman, J.A. (1993). Calibrating estimates of phageinduced mortality in marine bacteria: ultrastructural studies of marine bacteriophage development from one-step growth experiments. Microb. Ecol. 25, 161-182.

Puxty, R.J., Evans, D.J., Millard, A.D., and Scanlan, D.J. (2018). Energy limitation of cyanophage development: implications for marine carbon cycling. ISME J. 12, 1273-1286.

Puxty, R.J., Millard, A.D., Evans, D.J., and Scanlan, D.J. (2016). Viruses inhibit $\mathrm{CO}_{2}$ fixation in the most abundant phototrophs on earth. Curr. Biol. 26, 1585-1589.

Raymond, P.A., Hartmann, J., Lauerwald, R., Sobek, S., McDonald, C., Hoover, M., et al. (2013). Global carbon dioxide emission from inland waters. Nature. 503, 355359.

Riebesell, U., Gattuso, J.P., Thingstad, T.F., and Middelburg, J.J. (2013). Arctic ocean acidification pelagic ecosystem and biogeochemical responses during a mesocosm study. Biogeosciences. 10, 5619-5626.

Riebesell, U., Kortzinger, A., and Oschlies, A. (2009). Sensitivities of marine carbon fluxes to ocean change. Proc. Natl. Acad. Sci. USA. 106, 20602-20609. 
Rowe, J.M., Saxton, M.A., Cottrell, M.T., DeBruyn, J.M., Berg, G.M., Kirchman, D.L., et al. (2008). Constraints on viral production in the Sargasso Sea and North Atlantic. Aquat. Microb. Ecol. 52, 233-244.

Sano, E., Carlson, S., Wegley, L., and Rohwer, F. (2004). Movement of viruses between biomes. Appl. Environ. Microbiol. 70, 5842-5846.

Sarmiento, J.L., Slater, R., Barber, R., Bopp, L., Doney, S.C., Hirst, A.C., et al. (2004). Response of ocean ecosystems to climate warming. Global Biogeochem. Cycles 18, GB3003.

Smith, C.R., De Leo, F.C., Bernardino, A.F., Sweetman, A.K., and Arbizu, P.M. (2008). Abyssal food limitation, ecosystem structure and climate change. Trends Ecol. Evol. 23, 518-528.

Sullivan, M.B., Weitz, J.S., and Wilhelm, S. (2017). Viral ecology comes of age. Environ. Microbiol. Rep. 9, 33-35.

Suttle, C.A. (2005). Viruses in the sea. Nature. 437, 356-361.

Suttle, C.A. (2007). Marine viruses-major players in the global ecosystem. Nat. Rev. Microbiol. 5, 801-812.

Suttle, C.A., and Chen, F. (1992). Mechanisms and rates of decay of marine viruses in seawatert. Appl. Environ. Microbiol. 58, 3721-3729.

Thingstad, T.F. (2000). Elements of a theory for the mechanisms controlling abundance, diversity, and biogeochemical role of lytic bacterial viruses in aquatic systems. Limnol. Oceanogr. 45, 1320-1328.

Traving, S.J., Clokie, M.R.J., and Middelboe, M. (2014). Increased acidification has a profound effect on the interactions between the cyanobacterium Synechococcus sp. WH7803 and its viruses. FEMS Microbiol. Ecol. 87, 133-141.

Tsiola, A., Tsagaraki, T.M., Giannakourou, A., Nikolioudakis, N., Yücel, N., Herut, B., et al. (2017). Bacterial growth and mortality after deposition of Saharan dust and mixed aerosols in the Eastern Mediterranean Sea: a mesocosm experiment. Front. Mar. Sci. 3, 281.

Vaqué, D., Lara, E., Arrieta, J.M., Holding, J., Sà, E.L., Hendriks, I.E., et al. (2019). Warming and $\mathrm{CO}_{2}$ enhance Arctic heterotrophic microbial activity. Front. Microbiol. 10, 494.

Vaqué, D., Boras, J.A., Torrent-Llagostera, F., Agusti, S., Arrieta, J.M., Lara, E., et al. (2017). Viruses and protists induced-mortality of prokaryotes around the Antarctic Peninsula during the austral summer. Front. Microbiol. 8, 241. 
Vincent, W.F. (2010). Microbial ecosystem responses to rapid climate change in the Arctic. ISME J. 4, 1087-1090.

Wei, W., Wang, N., Cai, L., Zhang, C., Jiao, N., and Zhang, R. (2019). Impacts of freshwater and seawater mixing on the production and decay of virioplankton in a subtropical estuary. Microb. Ecol. 78, 843-854.

Wei, W., Zhang, R., Peng, L., Liang, Y., and Jiao, N. (2018). Effects of temperature and photosynthetically active radiation on virioplankton decay in the western Pacific Ocean. Sci. Rep. 8, 1525.

Weinbauer, M.G. (2004). Ecology of prokaryotic viruses. FEMS Microbiol. Rev. 28, $127-181$.

Weinbauer, M.G., Bettarel, Y., Cattaneo, R., Luef, B., Maier, C., Motegi, C., et al. (2009). Viral ecology of organic and inorganic particles in aquatic systems: avenues for further research. Aquat. Microb. Ecol. 57, 321-341.

Wells, L.E., and Deming, J.W. (2006). Effects of temperature, salinity and clay particles on inactivation and decay of cold-active marine Bacteriophage 9A. Aquat. Microb. Ecol. 45, 31-39.

Wilhelm, S.W., and Matteson, A.R. (2008). Freshwater and marine virioplankton: a brief overview of commonalities and differences. Freshw. Biol. 53, 1076-1089.

Wilhelm, S.W., and Suttle, C.A. (1999). Viruses and nutrient cycles in the sea: Viruses play critical roles in the structure and function of aquatic food webs. BioScience. 49, 781-788.

Williamson, S.J., and Paul, J.H. (2006). Environmental factors that influence the transition from lysogenic to lytic existence in the phiHSIC/Listonella pelagia marine phage-host system. Microb. Ecol. 52, 217-225.

Wilson, W.H., and Mann, N.H. (1997). Lysogenic and lytic production in marine microbial communities. Aquat. Microb. Ecol. 13, 95-100.

Wommack, K.E., and Colwell, R.R. (2000). Virioplankton: Viruses in aquatic ecosystems. Microbiol. Molec. Biol. Rev. 64, 69-114.

Yamada, Y., Tomaru, Y., Fukuda, H., and Nagata, T. (2018). Aggregate formation during the viral lysis of a marine diatom. Front. Mar. Sci. 5, 167.

Zhang, R., Weinbauer, M.G., and Qian, P.Y. (2007). Viruses and flagellates sustain apparent richness and reduce biomass accumulation of bacterioplankton in coastal marine waters. Environ. Microbiol. 9, 3008-3018. 
Zhang, R., Wei, W., and Cai, L. (2014). The fate and biogeochemical cycling of viral elements. Nat. Rev. Microbiol. 12, 850-851.

Zhou, J., Xue, K., Xie, J., Deng, Y., Wu, L., Cheng, X., et al. (2011). Microbial mediation of carbon-cycle feedbacks to climate warming. Nature Clim. Change. 2, 106-110.

Zimmerman, A.E., Howard-Varona, C., Needham, D.M., John, S.G., Worden, A.Z., Sullivan, M.B., et al. (2020). Metabolic and biogeochemical consequences of viral infection in aquatic ecosystems. Nat. Rev. Microbiol. 18, 21-34.

Zweimüller, I., Zessner, M., and Hein, T. (2008). Effects of climate change on nitrate loads in a large river: the Austrian Danube as example. Hydrol. Pro. 22, 1022-1036. 